
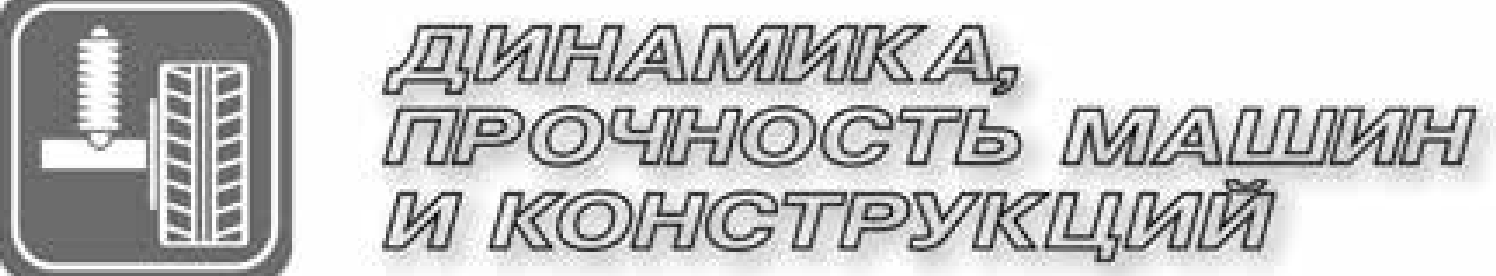

UDC 614.846.63:681.586.7

KOVTUN Vadim A., D. Sc. in Eng., Prof.

Professor of the Chair of Operational-Tactical Activity and Technical Equipment ${ }^{1}$

E-mail: vadimkov@yandex.ru

KOROTKEVICH Sergey G.

Lecturer of the Chair of Industrial Safety ${ }^{1}$

E-mail: korotkevichsergei@mail.ru

PLESKACHEVSKY Yury M., Corresponding Member of the NAS of Belarus,

D. Sc. in Eng., Prof.

Head of the Department "Micro- and Nanotechnology"2

E-mail: pleskym@mail.ru

${ }^{1}$ University of Civil Protection of the Ministry of Emergency Situations of the Republic of Belarus, Minsk, Republic of Belarus

${ }^{2}$ Belarusian National Technical University, Minsk, Republic of Belarus

Received 08 December 2020.

\title{
DAMAGE FEATURES OF TANKS OF FIRE TRUCKS AND STRENGTH ASSESSMENT OF THEIR WELDED JOINTS
}

The analysis of emergency rescue equipment usage on the territory of the Republic of Belarus made it possible to identify that the main technical unit involved into emergency situations is a fire truck tank. One of the main reasons for its repair and withdrawal from operational status is tank leakage that occurs due to peculiarities of equipment usage. As a result of a complex of studies, the recommendations for the modernization of a standard tank with $5 \mathrm{~m}^{3}$ volume of a fire truck were developed on the MAZ-5337 chassis. The stress state of a standard and modernized tank of a fire engine was investigated by the strain-gauge method under various operating modes of movement.

Keywords: fire truck, tank, modernization, mechanical stress, resistance-strain sensor, safety factor, welded joint, stiffener

DOI: https://doi.org/10.46864/1995-0470-2020-1-54-15-20

Introduction. The main special purpose vehicles include a fire truck tank. In the production of tanks of modern fire trucks, the rectangular shape has become the most widespread. This is due to the fact that the installation of such tanks makes it possible to use of the chassis width more completely, helps to reduce the center of mass of the vehicle and ensures the optimal location of a large number of transported emergency rescue equipment [1]. During the analysis, it was found that in the Republic of Belarus, as of 2020, 2,027 fire tankers are operated in fire rescue units, with the majority of them mounted on the chas- sis of the Minsk Automobile Plant - $65.8 \%$, the rest on the chassis of ZiL - $10.1 \%$, URAL $-11.4 \%$, KAMAZ - $9.5 \%$, of foreign manufacture $-3.2 \%$. At the same time, more than $85 \%$ of all fire tankers with a service life of up to 10 years are mounted on the chassis of domestic production.

The analysis of the number of repairs of fire tankers by the production and technical centers of the Ministry of Emergency Situations of the Republic of Belarus for 2016-2020 is carried out. As a result, it was found that one of the most common reasons for repairs is a leak in the welded joints of the tank. In the course of 
operation, cases were recorded when the first repair due to a leak in the tank of a fire truck was carried out in the first or second year of its operation in the emergency rescue unit. As a result of surveys and repair work, it was found that the main places prone to leaks are the welded joints of the breakwaters with the tank shell, as well as corner welds. The integrity of the tank of a fire truck determines the constant readiness for combat work. Repair of the resulting damage of the tank requires a large amount of preparation: shipping a car in the production technology center, dismantling and assembling, welding work, the use of repair materials, which leads to downtime of the equipment and reduction of the combat capability of the unit for an extended period of time. The analysis of the causes and factors that lead to premature repair and restoration work of tank structures of fire trucks showed that they are primarily due to the daily operation of fire trucks, associated with the need for rapid movement to the place of emergency situations, resulting in cyclic re-variable loads in the "acceleration", "braking", "turn" modes [2]. In the Republic of Belarus, more than 3,000 fires occur annually in rural areas and more than 1,000 fires in natural ecosystems, which is about 60 and $20 \%$, respectively, of the total number of fires [3]. As a result, fire trucks have to carry out rapid movement on country roads, as well as in off-road conditions. At the same time, the tank walls experience large loads transmitted through the chassis frame, which occur when a fire truck is moving and depend on the nature of the terrain, as well as on the dynamic pressure of the liquid being transported. The combined effect of these factors causes leaks in the tank structure due to the formation of fatigue cracks. One of the ways to solve this problem is the scientifically based design of tank structures of fire trucks, which is a complex technical task.

In order to solve the given task, a new methodological approach is created consisting in developing the calculated finite element models in ANSYS software package, which consider experimental data obtained using vibrodiagnostic complex [2]. This made it possible to assess the stress-strain state of shell-type structures, taking into account the operational modes of movement and terrain [3]. The studies were carried out for one of the most common models of a fire truck on the territory of the Republic of Belarus on the MAZ-5337 chassis with a tank of $5 \mathrm{~m}^{3}$ volume, the number of repairs due to tank leaks is $9-15 \%$ per year of the total number. The tank structure is a rectangular tank formed by the front, rear, side walls, bottom and roof. There are stiffeners, longitudinal and transverse breakwaters inside the tank. In the course of numerous surveys, no significant corrosion effect on the design of tanks of this type was found, which can lead to leaks, which is associated with the use of high-quality stainless steel of the AISI $4302 \mathrm{~B}$ brand in the production. As a result of a complex of studies, recommendations for the moder- nization of standard tank of the fire truck were made [4-7], the implementation of which reduces the level of stresses in the areas of welded joints: application of the four joint plates in the form of a strip with dimensions of $900 \times 150 \times 3 \mathrm{~mm}$ in the vertical plane at a $45^{\circ}$ angle to come in contact with the walls; increasing the length by $250 \mathrm{~mm}$ (maximum value) in the upper and lower parts of the four stiffeners in the form of an equal angle with dimensions of $700 \times 60 \times 3 \mathrm{~mm}$, located on the side walls at an angle of $45^{\circ}$; using equal flange U-shaped sections with dimensions of $50 \times 50 \times 3 \mathrm{~mm}$ (two pieces with a length of $300 \mathrm{~mm}$, four $-400 \mathrm{~mm}$, two $-780 \mathrm{~mm}$ ), fixed on the bottom at a distance of $15-20 \mathrm{~mm}$ from the corner welds of the front, rear walls and bottom.

Figure 1 shows a fragment of the corner weld of the side and front walls of the tank of a fire truck on the MAZ-5337 chassis that has left the warranty period of service, which reflects the implementation of recommendations for the structure modernization.

Depending on the purpose of the design, the value of the minimum required safety factor is set. To ensure the strength and durability of the structure, as well as taking into account the experience of operating similar structures, the safety factors are normalized. In mechanical engineering, the standard safety factor for various parts is in the range of 1.4-1.7 [2]. In the case of special requirements for the strength of the part, this factor is increased to 3 , and in some cases to higher values. The need to introduce a safety factor is associated with a number of circumstances: the calculated loads are not completely reliable; the possibility of overloads is not excluded; methods for determining forces in structural elements in most cases have some conventions; cross-section dimensions have deviations, and also change due to wear and corrosion; strength and ductility characteristics have deviations for batches of one material; dynamic load and stress concentration are possible.

Thus, the aim of this work was experimental confirmation of the effectiveness of the developed methods

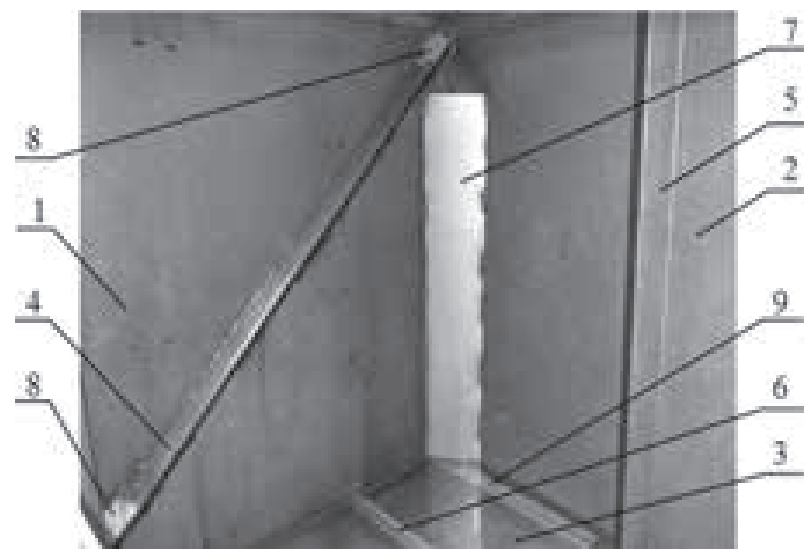

Figure 1 - Fragment of the internal corner weld of side and front walls of the tank: 1 - side wall; 2 - front wall; 3 - bottom; 4 - stiffener on the side wall; 5 - stiffener on the front wall; 6 - U-shaped section; 7 - joint plate; 8 - elongation of the stiffener on the side wall; 9 - additional U-shaped section 
and recommendations to enable improved operational reliability and safety factor of fire truck tanks operating in emergency rescue units on the territory of the Republic of Belarus.

Strain-gauge testing. The resulting mechanical stresses in the structures of a standard and modernized tank with a $5 \mathrm{~m}^{3}$ volume of a fire truck on the MAZ-5337 chassis were studied using a measuring strain-gauge complex. The strain-gauge complex consisted of a portable computer with special software installed, a receiver and strain-gauge sensors. A portable precision instrument of the MT-D4 model was used as a receiving device [8]. It is designed for digital processing of signals transmitted from strain-gauge sensors connected to it. To control the MT-D4 device and display the measurement results, a personal computer based on MS Windows with special software installed was used. General-purpose linear resistance-strain sensors of the CEA-06250UW-120 type were used to measure mechanical stresses. The sensor design consists of a foil tape with a thickness of up to $12 \mu \mathrm{m}$, a substrate and contacts with external terminals. The principle of its operation is based on the piezoresistance effect, the property of conductors and semiconductors to change the electrical resistance during volumetric or linear deformation [9]. The foil sensing element is made of a constantan alloy in a thermocompensation shell. The base of the sensor substrate consists of polyamide. This type of resistance-strain sensors is capable of measuring voltages in static and dynamic modes, has a low resistance of $120 \pm 0.3 \% \Omega$, has the ability to measure deformations in the range of $\pm 5 \%$, is used in the temperature range from $-75^{\circ} \mathrm{C}$ to $+175{ }^{\circ} \mathrm{C}$. The installation of measuring sensors was carried out in a heated room on the previously cleaned surface of the outer walls of the tank [10]. The control points identified the areas of welded joints of the tank that are subject to the greatest loads during operation and were strengthened during the modernization. The surface on which the sensors were attached had a roughness of no more than $400 \mu \mathrm{m}$. Temperature compensation of the sensors at a room temperature of $+22{ }^{\circ} \mathrm{C}$ was not required.

The following operating modes are selected for the fire truck that are close to the conditions of its effective movement: mode no. 1 - movement on a straight section of smooth asphalt road at a speed of $50 \mathrm{~km} / \mathrm{h}$; mode no. 2 - movement on the uneven road at a speed of 20-30 km/h; mode no. 3 - sharp turn at a speed of $10-15 \mathrm{~km} / \mathrm{h}$; mode no. 4 - acceleration from a standstill to a speed of $30 \mathrm{~km} / \mathrm{h}$ and braking.

Initially, the research was carried out on a standard tank with a $5 \mathrm{~m}^{3}$ volume of a fire truck on the MAZ-5337 chassis. Table 1 shows information about the controlled areas of the tank structure, the number of sensors and ways to place them. Studies have shown that sensors nos. 1, 2, which are installed horizontally in the corner weld of the front and side walls, and nos. 3, 4, which are installed vertically in the corner weld of the front wall and bottom, record the highest values of mechanical stresses. This indicates that when in a tank of a fire truck during operation, tensile stresses prevail [11-12]. Tests of the modernized tank of the fire truck were carried out under similar conditions. Based on the obtained results of mechanical stress measurements on the standard tank, sensors nos. 9, 10, 11, 12 were installed on the modernized tank similarly to sensors no. 1, 2, 3, 4 .

In order to accurately determine the direction of deformation, taking into account the capabilities of the receiving device, 8 sensors were used, which were installed on the surface of the tank walls horizontally, vertically and at an angle of $45^{\circ}$ in the most subjected to load areas of the structure (Figure 2).

Figures 3 and 4 show the results of studies of mechanical stresses by sensors no. 1 and no. 9, which were installed in the area of the corner weld of the front and side walls of the standard and modernized tank of the fire truck, respectively. The software recorded the emerging voltages at the sensor report rate $v=0.25 \mathrm{~s}$. Operating modes of movement of a fire truck with a standard tank are correlated with the following time intervals (see Figure 3 ): mode no. 1 (1-141 s; 521-664 s); mode no. 2 (316-520 s); mode no. 3 (142-315 s); mode no. 4 (665-850 s). Operating modes of movement of a fire truck with a modernized tank are correlated with the following time intervals (see Figure 4): mode no. 1 (1-98 s; 311-510 s); mode no. 2 (650-770 s); mode no. 3 (99-310 s); mode no. 4 (511-649 s).

Table 2 shows the maximum values of tensile mechanical stresses recorded by the strain-gauge complex during tests on standard and modernized tanks with $5 \mathrm{~m}^{3}$ volume of a fire truck on the MAZ-5337 chassis.

The experimental research of the stress state of the corner welds of standard and modernized tank with $5 \mathrm{~m}^{3}$ volume of the fire truck on the MAZ-5337

Table 1 - Arrangement of resistance-strain sensors on the outer surface of the standard tank walls of the fire truck

\begin{tabular}{|c|c|c|c|}
\hline \multirow{2}{*}{ Installation areas of sensors } & \multicolumn{3}{|c|}{ Sensor arrangement method } \\
\hline & horizontally & vertically & at an angle $45^{\circ}$ \\
\hline \multirow{2}{*}{ Corner weld of the front and side walls } & no. 1 & no. 5 & - \\
\hline & no. 2 & - & no. 7 \\
\hline \multirow{2}{*}{ Corner weld of the front wall and bottom } & no. 6 & no. 3 & - \\
\hline & - & no. 4 & no. 8 \\
\hline
\end{tabular}



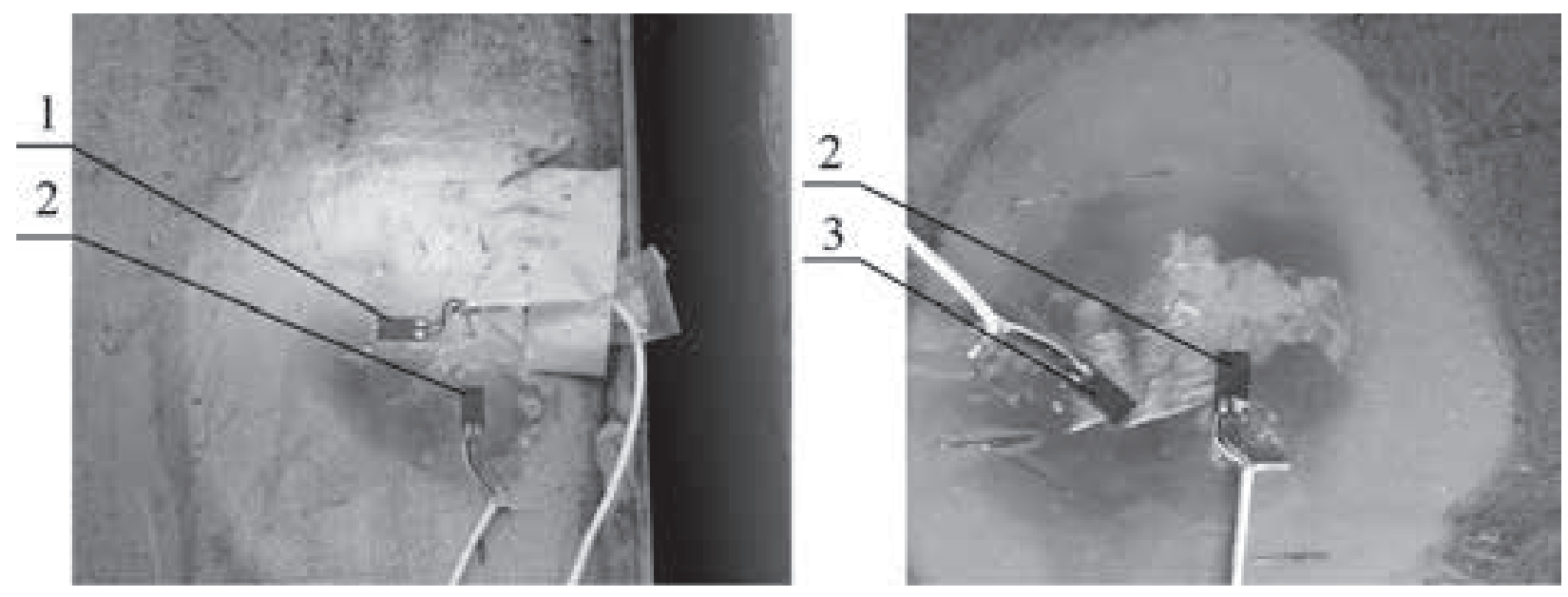

Figure 2 - Arrangement of sensors on the outer surface of the standard tank walls of the fire truck relative to horizon: 1 - horizontally; 2 - vertically; 3 - at an angle $45^{\circ}$

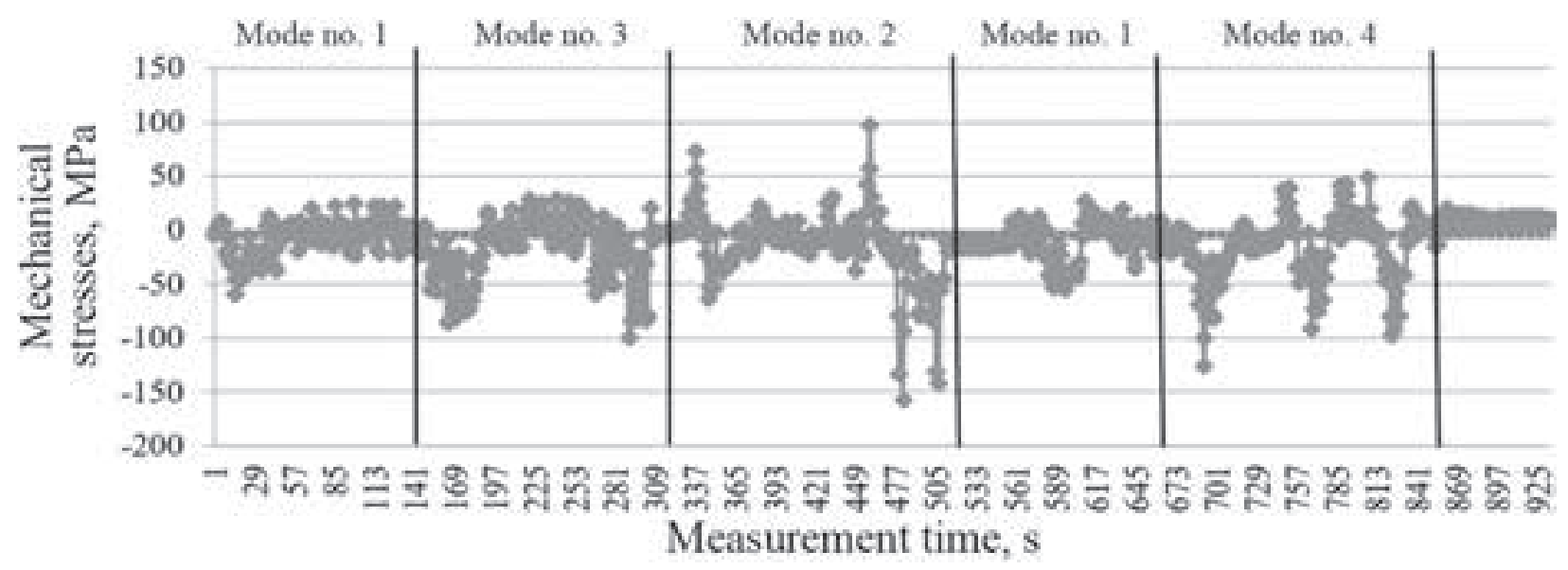

Figure 3 - Dependence of the influence of the fire truck movement modes on the emerging mechanical stresses in a standard tank structure

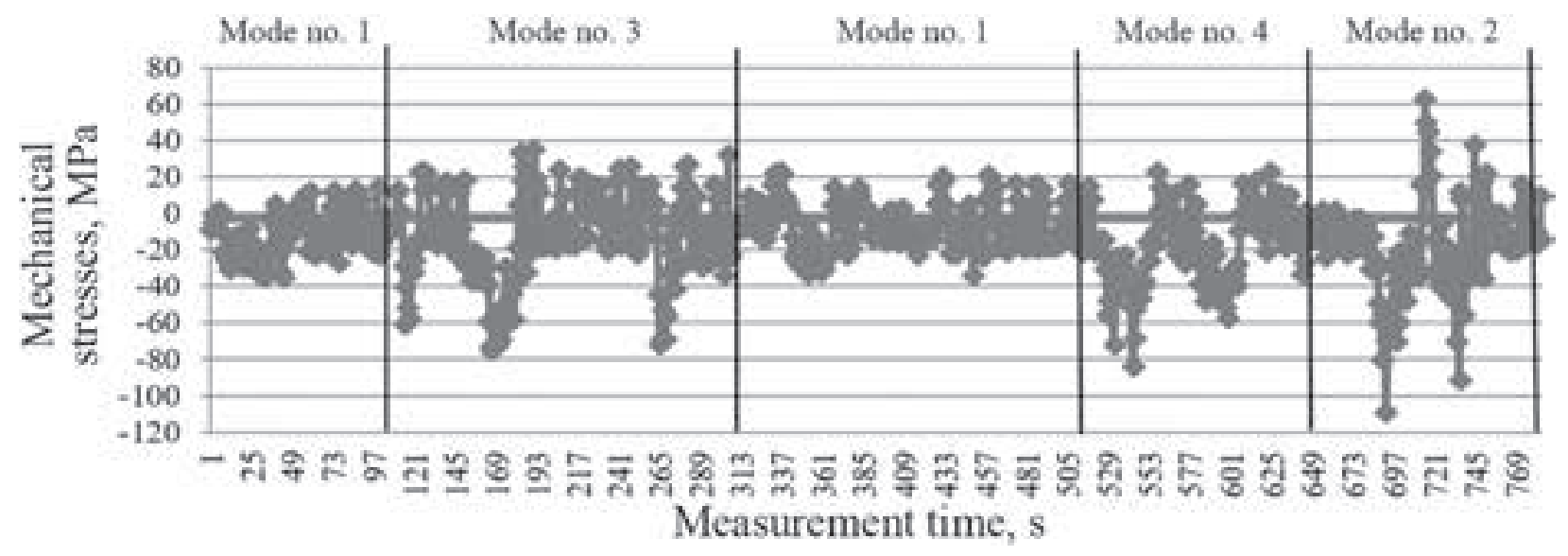

Figure 4 - Dependence of the influence of the fire truck movement modes on the emerging mechanical stresses in a modernized tank structure

Table 2 - Maximum values of tensile mechanical stresses in the areas of corner welds of fire truck tanks

\begin{tabular}{|l|c|c|}
\hline \multicolumn{1}{|c|}{ Areas of welded joints } & Standard tank, $\sigma_{\max }, \mathrm{MPa}$ & Modernized tank, $\sigma_{\max }, \mathrm{MPa}$ \\
\hline Corner weld of the front and side walls & $150-158$ & $100-108$ \\
\hline Corner weld of the front wall and bottom & $161-173$ & $138-149$ \\
\hline
\end{tabular}

chassis confirmed reduction of the stress level by $14-32 \%$ in area of corner welds of modernized structure compared to the standard one.
Conclusion. Experimental studies were carried out on stress state of the standard and modernized tank with $5 \mathrm{~m}^{3}$ volume of fire trucks on the MAZ-5337 
chassis under various operating modes of movement. Analysis of the research results made it possible to establish that when a fire emergency vehicle is moving, the stress state of the tank is largely determined by both the geometric parameters of its structural elements and the mode of movement. It is determined that the maximum values of mechanical stresses occur when a fire truck moves along a country uneven road at a speed of $20-30 \mathrm{~km} / \mathrm{h}$, while a decrease in the stress level by $14-32 \%$ is established in the areas of corner welds of the modernized tank compared to the standard one. It is established that modernization of tanks of fire trucks makes it possible to reduce considerably the arising stresses in the course of operation, in particular, in its corner welds.

The results obtained confirm the effectiveness of the modernization of fire emergency vehicles on the MAZ-5337 chassis and make it possible to recommend the development for implementation in the bodies and departments of emergency situations when carrying out major repairs of operated truck tanks.

\section{References}

1. Bezborodko M.D. Pozharnaya tekhnika [Firefighting equipment]. Moscow, Akademiya GPS MChS Rossii Publ., 2015. 580 p. (in Russ.).

2. Vysotskiy M.S., Pleskachevsky Yu.M., Shimanovskiy A.O. Dinamika avtomobilnykh i zheleznodorozhnykh tsistern [Dynamics of truck and rail tanks]. Minsk, Belavtotraktorostroenie Publ., 2006. 320 p. (in Russ.).

3. Svedeniya o chrezvychaynykh situatsiyakh [Information about emergency situations]. Available at: https://mchs.gov.by/operativnaya-informatsiya/sutochnye-svodki-mchs/v-rb/333754/ (accessed 20 January 2021).

4. Kovtun V.A., Korotkevich S.G., Zharanov V.A. Kompyuternoe modelirovanie $\mathrm{i}$ issledovanie napryazhenno-deformirovanno- go sostoyaniya konstruktsiy tsistern pozharnykh avtomobiley [Computer simulation and research of the stress-strain state of fire tank truck structures]. Journal of civil protection, 2018, vol. 2, no. 1, pp. 81-90. DOI: https://doi.org/10.33408/2519237X.2018.2-1.81 (in Russ.).

5. Kovtun V.A., Korotkevich S.G., Pasovets V.N. Pozharnaya tsisterna [Fire tank]. Utility model RB, no. 11787, 2018 (in Russ.).

6. Kovtun V.A., Korotkevich S.G. Tsisterna pozharnogo avtomobilya [Fire truck tank]. Utility model, no. u 20200103, 2020 (in Russ.).

7. Kovtun V.A., Korotkevich S.G. Issledovanie vliyaniya geometricheskikh parametrov elementov konstruktsii tsisterny na ee prochnostnye kharakteristiki pri modernizatsii pozharnykh avtomobiley [Research of the geometric parameters influence of tank constructional elements on its strength characteristics at modernization of fire-fighting trucks]. Journal of civil protection, 2020, vol. 4, no. 3, pp. 316-327. DOI: https://doi. org/10.33408/2519-237X.2020.4-3.316 (in Russ.).

8. Specialty instruments for strain gage measurement. Available at: https://micro-measurements.com/instruments (accessed 23 July 2019).

9. Akhmedzhanov R.A., Cheredov A.I. Fizicheskie osnovy polucheniya informatsii [Physical basics of getting information]. Omsk, Omskogo gosudarstvennogo tekhnicheskogo universiteta Publ., 2008. 184 p. (in Russ.).

10. Mekheda V.A. Tenzometricheskiy metod izmereniya deformatsiy [Strain gauge method for measuring strain]. Samara, Samarskogo gosudarstvennogo aerokosmicheskogo universiteta Publ., 2011. 56 p. (in Russ.).

11. Kovtun V.A., Korotkevich S.G., Lodnya V.A. Osobennosti formirovaniya napryazhenno-deformirovannogo sostoyaniya uglovykh svarnykh soedineniy tsistern pri dvizhenii pozharnogo avtomobilya [Formation features of the stress-strain state of tank corner joints during the fire truck movement]. Vestnik GGTU imeni P.O. Sukhogo, 2020, no. 2, pp. 59-67. (in Russ.).

12. Korotkevich S.G., Kovtun V.A. 3D kompyuternoe modelirovanie napryazhennogo sostoyaniya uglovykh svarnykh soedineniy stenok tsisterny pozharnogo avtomobilya pri dvizhenii [3D computer modeling of stress state in the fillet weld of tank's walls of a fire truck at movement]. Machines and mechanisms reliability and durability, 2020, pp. 210-214 (in Russ.).

В.А. КОВТУН, д-р техн. наук, проф.

профессор кафедры оперативно-тактической деятельности и техники ${ }^{1}$

E-mail: vadimkov@yandex.ru

\section{С.Г. КОРОТКЕВИЧ}

преподаватель кафедры промышленной безопасности ${ }^{1}$

E-mail: korotkevichsergei@mail.ru

Ю.М. ПЛЕСКАЧЕВСКИЙ, чЛ.-корр. НАН Беларуси, д-р техн. наук, проф. заведующий кафедрой «Микро- и нанотехника»²

E-mail: pleskym@mail.ru

${ }^{1}$ Университет гражданской защиты МЧС Беларуси, г. Минск, Республика Беларусь

${ }^{2}$ Белорусский национальный технический университет, г. Минск, Республика Беларусь

\section{ОСОБЕННОСТИ ПОВРЕЖДЕНИЙ ЦИСТЕРН ПОЖАРНЫХ АВТОМОБИЛЕЙ И ОЦЕНКА ПРОЧНОСТИ ИХ СВАРНЫХ СОЕДИНЕНИЙ}

Анализ применения аварийно-спасательной техники на территории Республики Беларусь позволил установить, что основной технической единицей в привлечении на ликвидацию чрезвычайных ситуаций является пожарная автоцистерна. Одной из причин ее ремонта и вывода из боевого расчета 
является нарушение герметичности цуистерны, что происходит вследствие особенностей эксплуатациии техники. В результате проведенного комплекса исследований разработань рекомендации по модернизаиии серийной ичстерны объемом 5 м $^{3}$ пожарного автомобиля на шасси МАЗ-5337. Методом тензометрии исследовано напряженное состояние серийной и модернизированной цฺистерны пожарного автомобиля при различных эксплуатационных режимах движения.

Ключевые слова: пожарный автомобиль, ичистерна, модернизация, механические напряжения, тензорезистивный датчик, запас прочности, сварное соединение, ребро жесткости

DOI: https://doi.org/10.46864/1995-0470-2020-1-54-15-20

\section{Список литературы}

1. Пожарная техника: учеб. / М.Д. Безбородько [и др.]; под ред. М.Д. Безбородько. - М.: Академия ГПС МЧС России, 2015. $-580 \mathrm{c}$.

2. Высоцкий, М.С. Динамика автомобильных и железнодорожных цистерн / М.С. Высоцкий, Ю.М. Плескачевский, А.О. Шимановский. - Минск: Белавтотракторостроение, 2007. - $320 \mathrm{c}$

3. Сведения о чрезвычайных ситуациях // МЧС Республики Беларусь [Электронный ресурс]. — 2021. — Режим доступа: https://mchs.gov.by/operativnaya-informatsiya/sutochnyesvodki-mchs/v-rb/333754/. — Дата доступа: 20.01.2021.

4. Ковтун, В.А. Компьютерное моделирование и исследование напряженно-деформированного состояния конструкций цистерн пожарных автомобилей / В.А. Ковтун, С.Г. Короткевич, В.А. Жаранов // Вестн. ун-та граждан. защиты МЧС Беларуси. - 2018. - Т. 2, № 1. - C. 81-90. DOI: 10.33408/2519-237X.2018.2-1.81.

5. Пожарная цистерна: полез. модель ВY 11787 / В.А. Ковтун, С.Г. Короткевич, В.Н. Пасовец. - Опубл. 30.10.2018.

6. Цистерна пожарного автомобиля: полез. модель BY № u 20200103 / В.А. Ковтун, С.Г. Короткевич.

7. Ковтун, В.А. Исследование влияния геометрических параметров элементов конструкции цистерны на ее прочностные характеристики при модернизации пожарных автомобилей / В.А. Ковтун, С.Г. Короткевич // Вестн. ун-та граждан. защиты МЧС Беларуси. - 2020. - Т. 4, № 3. C. 316-327. DOI: 10.33408/2519-237X.2020.4-3.316

8. D4 Data Acquisition Conditioner [Electronic resource]. - Mode of access: https://micro-measurements.com/instruments. — Date of access: 23.07.2019.

9. Ахмеджанов, Р.А. Физические основы получения информации: учеб. пособие / Р.А. Ахмеджанов, А. И. Чередов. Омск: Изд-во ОмГТУ, 2008. - 184 с.

10. Мехеда, В.А. Тензометрический метод измерения деформаций: учеб. пособие / В.А. Мехеда. - Самара: Изд-во Самар. гос. аэрокосм. ун-та, 2011. - 56 с.

11. Ковтун, В.А. Особенности формирования напряженно-деформированного состояния угловых сварных соединений цистерн при движении пожарного автомобиля / В.А. Ковтун, С.Г. Короткевич, В.А. Лодня // Вестн. ГГТУ им. П.О. Сухого. — 2020. — № 2(81). — С. 59-67.

12. Короткевич, С.Г. 3D компьютерное моделирование напряженного состояния угловых сварных соединений стенок цистерны пожарного автомобиля при движении / С.Г. Короткевич, В.А. Ковтун // Надежность и долговечность машин и механизмов: сб. матер. XI Bcерос. науч.-практ. конф., Иваново, 16 апр. 2020 г. / ФГБОУ ВО Ивановская пожарно-спасательная академия ГПС МЧС России; редкол.: В.А. Годлевский [и др.]. — Иваново, 2020. — С. 210-214. 